\title{
O SURGIMENTO/DESCOBERTA DE UM NOVO DIREITO E DE UMA NOVA POLITTICA E A REVOLUÇÃO FRANCESA
}

THE EMERGENCE/DISCOVERY OF A NEW LAW AND A NEW POLICY AND THE FRENCH REVOLUTION

\section{EL SURGIMIENTO/DESCUBRIMIENTO DE UN NUEVO DERECHO Y DE UNA NUEVA POLÍTICA Y LA REVOLUCIÓN FRANCESA}

\section{Daniela Mesquita Leutchuk de Cademartori ${ }^{1}$}

\section{Sergio Urquhart de Cademartori ${ }^{2}$}

Licença CC BY:

Artigo distribuído sob os termos Creative Commons, permite uso e distribuição irrestrita em qualquer meio desde que o autor credite a fonte original.

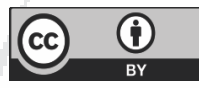

\begin{abstract}
Resumo: Este ensaio busca - partindo da Revolução Francesa - perceber o surgimento/descoberta de uma nova política e, portanto, de um novo direito que irá se irradiar nos momentos seguintes, marcando o que hoje se conhece como Constitucionalismo contemporâneo. Partindo da análise de conceitos, tais como o de privilégio, o da ideologia da democracia pura ou do jacobinismo, atinge a percepção de uma nova mentalidade, bem como os problemas que afligem a democracia. Neste sentido, a Revolução desencadeia um novo mundo que é percebido como uma linguagem. Algumas contribuições teóricas, como a de Tocqueville no século XIX e a e de Habermas no século XX, são cruciais, dado que o primeiro, preocupado em explicar as continuidades entre os períodos pré e o pós-revolucionários, apresenta um aporte metodológico fundamental ao tema da diferença entre reforma e Revolução; já o segundo, ao salientar a consciência revolucionária, evidencia o início de uma nova mentalidade sobre o tempo, sobre a prática política e sobre a legitimação do direito. O trabalho parte da constatação de que a complexidade da relação entre o direito e a política percebida a partir de acontecimentos relacionados à Revolução Francesa deve ser trabalhada de modo transdisciplinar, considerando em especial as abordagens da teoria da história à teoria política e à teoria do direito. A trajetória metodológica é qualitativa, sendo utilizada a pesquisa bibliográfica como forma de coleta de dados.
\end{abstract}

1 Doutora e Mestre em Direito pela UFSC. Professora da Graduação e da Pós-Graduação (Mestrado e Doutorado) em Direito da Unilasalle, Canoas-RS. E-mail: daniela.cademartori@unilasalle.edu.br

2 Doutor em Direito pela UFSC e Professor do UniFG (BA) e da Unilasalle, Canoas-RS. E-mail: sucademartori@ gmail.com.br 
Palavras-Chave: Direito; Política; Democracia; Esfera Pública; Constitucionalismo; Revolução Francesa.

Abstract: Taking the French Revolution as its starting point, this essay seeks to understand the emergence/discovery of a new policy and, therefore, a new right that will radiate in the following moments, marking what we know today as contemporary Constitutionalism. Starting from the analysis of concepts such as privilege, the ideology of pure democracy or Jacobinism, one reaches the perception of a new mentality, as well as the problems that afflict democracy. In this sense, the Revolution unleashes a new world that is perceived as a language. Some theoretical contributions, such as those of Tocqueville in the nineteenth century and Habermas in the twentieth century, are crucial, since the former, concerned with explaining the continuities between the pre- and postrevolutionary periods, presents a fundamental methodological approach to the theme of the difference between reform and Revolution; the second, in emphasizing the revolutionary conscience, highlights the beginning of a new mentality about time, about political practice, and about the legitimation of the law. The work starts from the realization that the complexity of the relationship between law and politics, perceived through events related to the French Revolution, must be analyzed in a transdisciplinary way, considering in particular the approaches of theory of history to political theory and theory of law. The methodological trajectory is qualitative, using bibliographic research as a form of data collection.

Keywords: Law; Politics; Democracy; Public Sphere; Constitutionalism; French Revolution.

Resumen: Este ensayo busca - partiendo de la Revolución Francesa - percibir el surgimiento/ descubrimiento de una nueva política y, por lo tanto, de un nuevo derecho que se irá irradiar en los momentos siguientes, marcando lo que hoy se conoce como Constitucionalismo contemporáneo. Partiendo del análisis de conceptos, tales como el de privilegio, el de la ideología de la democracia pura o del jacobinismo, alcanza la percepción de una nueva mentalidad, bien como los problemas que afligen la democracia. En este sentido, la Revolución desencadena un nuevo mundo que es percibido como un lenguaje. Algunas contribuciones teóricas, como la de Tocqueville en el siglo XIX y la de Habermas en el siglo XX, son cruciales, dado que el primero, preocupado en explicar las continuidades entre los períodos pre y el pos-revolucionarios, presenta un aporte metodológico fundamental al tema de la diferencia entre reforma y Revolución; ya el segundo, al destacar la consciencia revolucionaria, evidencia el inicio de una nueva mentalidad sobre el tiempo, sobre la práctica política y sobre la legitimación del derecho. El trabajo parte de la constatación de que la complejidad de la relación entre el derecho y la política percibida a partir de acontecimientos relacionados a la Revolución Francesa debe ser trabajada de modo transdisciplinar, considerando en especial los abordajes de la teoría de la historia a la teoría política y a la teoría del derecho. La trayectoria metodológica es cualitativa, siendo utilizada la investigación bibliográfica como forma de recolección de datos.

Palabras-Clave: Derecho; Política; Democracia; Esfera Pública; Constitucionalismo; Revolución Francesa. 


\section{INTRODUÇÃO}

Neste artigo, busca-se a relação entre a política ou a democracia e o direito, no caso os direitos humanos, por meio da análise de aspectos históricos e teóricos levantados pela Revolução Francesa. Em primeiro lugar, é importante começar pela crítica à própria ideia de Revolução, que envolve a noção de uma mudança radical, origem de um tempo novo, em oposição à ideia de reforma. Embora o evento Revolução Francesa demarque um período limitado da história desse país, que se estende de 1789 a 1799, suas repercussões são mundiais e atemporais. As causas são variadas e distantes, envolvendo as lutas pela liberdade, pela justiça e pelo bem comum que fazem com que a Europa crie paradigmas que passam a fazer parte do legado cultural da humanidade. Neste ponto, a cultura jurídica europeia se contrapõe a culturas de outras áreas geográficas justamente porque a grande maioria de seus elementos nasce com a vocação jurídica de universalidade, em especial os direitos humanos, a dignidade humana - como premissa antropológica, sentido e objetivo da ordem política -, a doutrina da justiça, o princípio democrático, o Estado de direito e a divisão de poderes e até mesmo a economia de mercado.

Para traçar um panorama do novo que surge - especialmente na política e no direito - a partir da Revolução Francesa, indispensável se faz ressaltar que o conceito de Constitucionalismo ocupa lugar central, compreendido como constitucionalismo "político" ou uma concepção teórica e prática dos poderes públicos na perspectiva da sua limitação, garantidora de determinados âmbitos da liberdade. ${ }^{3}$ A ele se conectam a luta pela justiça e a democracia, refletidas nos inúmeros temas associados a 1789, dentre eles a superação do conceito de privilégio, a compreensão do jacobinismo como sociedade de pensamento prefiguradora da democracia - e da própria democracia em suas variadas formas.

3 Para Ferrajoli o Constitucionalismo jurídico deve ser percebido como um conjunto de limites e vínculos formais e substanciais, impostos de forma rígida, a todas as fontes normativas. Como teoria do direito equivale "a uma concepção de validade das leis que não está mais ancorada apenas na conformidade das suas formas de produção a normas procedimentais sobre a sua elaboração, mas também na coerência dos seus conteúdos com os princípios de justiça constitucionalmente estabelecidos." (FERRAJOLI, L. Constitucionalismo principialista e constitucionalismo garantista. Tradução de A. K. Trindade. In: ; STRECK, Lenio Luiz; TRINDADE, André Karam (orgs.). Garantismo, hermenêutica e (neo)constitucionalismo: um debate com Luigi Ferrajoli. Porto Alegre: Livraria do Advogado, 2012. p. 13-14). 


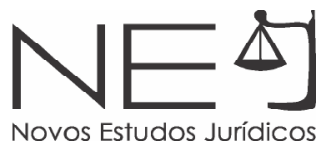

\section{COMBATE AOS PRIVILÉGIOS E UM NOVO MÉTODO PARA ANALISAR A REVOLUÇÃO}

Uma série de acontecimentos determinaram a "explosão" da Revolução Francesa ${ }^{4}$. Fato notório é o de que, a partir de 1787, o reino da França era uma sociedade sem governo. Luís XVI ainda mantinha o consenso dos súditos em torno de si; porém paulatinamente a autoridade real sofria um processo de deslegitimação, motivado por "maus ministros, conselheiros pérfidos, intendentes nefastos". A esta situação alia-se uma crise econômica complexa, simultaneamente agrícola, industrial, meteorológica e social. ${ }^{5}$

Aliada à crise da monarquia, a Revolução Americana acabou por revelar-se como uma importante causa imediata da Revolução Francesa. Ela havia deixado como elementos alimentadores de rebelião a sua "Carta de Direitos" e o próprio deficit financeiro que a ajuda francesa acabou por produzir. Na tentativa de estancar a crise financeira com uma reforma fiscal, Luís XVI desencadeia um processo eleitoral - abolindo na prática a censura -, de modo a constituir os Estados Gerais, instância com poderes para promovê-la. A grande novidade das regras eleitorais é o seu pioneirismo: as cartas de convocação, apesar de apresentarem um texto contraditório e ambíguo, foram reunidas em um "verdadeiro código eleitoral cuja minúcia, a preocupação sem precedentes com a unidade e a equidade, demonstrava uma transformação no direito público". ${ }^{6}$

$4 \quad$ Muito mais do que um acontecimento limitado à França, a Revolução deve ser vista de modo a considerar a série de revoluções que explodiram de um lado a outro do oceano Atlântico. "Ela não só transformou o regime político da França, como alterou os modos de vida, a organização econômica e social. Foi também o que hoje chamamos de 'revolução cultural'." É preciso considerar a Revolução Americana (1770-1783), a Francesa, passando pelas Revoluções Holandesa (1783-1787), Belga (1787-1790), Genebrina (1792). Após modificarem a Europa, atravessaram novamente o Atlântico a partir de 1808, para culminar na independência das colônias espanholas e portuguesa da América. (GODECHOT, Jacques. A Revolução Francesa: cronologia comentada 1789-1799. Tradução de Julieta Leite. Rio de Janeiro: Nova Fronteira, 1989, p. 9 e 415).

5 FURET, François. Pensando a Revolução Francesa. Tradução de Luiz Marques e Martha Gambini. 2. ed. São Paulo: Paz e Terra, 1989, p. 39-40.

6 Mantida a separação por ordens, o Terceiro Estado teve sua representação praticamente duplicada em relação aos Estados Gerais de 1614 sem que fosse aceita a reivindicação da "votação por cabeça". Estas regras acabaram por consagrar a representação política moderna: o direito de sufrágio a todos os integrantes do Terceiro Estado com idade mínima de 25 anos e inscritos no registro de impostos; a não distinção entre direito de eleição e direito de elegibilidade, podendo ser candidato todo indivíduo com acesso às assembleias eleitorais; e, finalmente a igualdade política. Este último princípio fez com que "pela primeira vez, o povo penetrava [sse] de direito maciçamente na vida política. O eleitorado assim criado chegava a cerca de seis milhões - à época, a maior representação política já ativada no mundo." (PÉRONNET, Michel. A Revolução Francesa em 50 palavraschaves. Prefácio de Jacques Godechot. Tradução de Rita Braga. São Paulo: Brasiliense, 1983. p. 125). 


\subsection{O SUBSTRATO CULTURAL: O ILUMINISMO}

A presença na França de uma corrente de pensamento, composta por pensadores que haviam lido obras como o tratado "Dos delitos e das penas", em que o jurista Beccaria denunciava a tortura e as penas cruéis ${ }^{7}$ e tinha como intenção política evidente desnudar as relações de poder no Estado absolutista e semifeudal, foi decisiva nos acontecimentos relacionados à Revolução. ${ }^{8}$ Esta "verdadeira equipe de intelectuais", ou seja, os representantes do lluminismo9, acabou por desencadear uma revolução cultural. A divulgação das ideias ficava a cargo das gazetas ou dos jornais, das associações e da publicação de milhares de brochuras pré-revolucionárias, que em meio ao combate encarregaram-se de divulgá-las. Mesmo que de modo abreviado, os populares - e, na época, mais da metade da população adulta francesa sabia ler e escrever - tomavam conhecimento das ideias iluministas.

Neste sentido, uma importante mudança operada pelo lluminismo foi a do significado da expressão "privilégio". De algo puramente legal - direitos apoiados em lei -, o termo passa a designar algo pejorativo, apontando vantagens adquiridas por meio de esforços ilegítimos. ${ }^{10}$ Até então, um privilégio era um atributo da pessoa em decorrência de seu pertencimento a um grupo particular, ou mesmo poderia ser propriedade de um indivíduo (o que ocorria quando o rei fazia uma concessão a um favorito durante a sua vida, relativa ao pagamento de determinado imposto ou à isenção de qualquer direito alfandegário). No caso francês, os grupos privilegiados representavam

7 "Na França, Montesquieu, Voltaire, Rousseau, Diderot, cada um com seu estilo fizeram ressoar a voz da filosofia. Contra a intolerância religiosa e em defesa das liberdades, contra o arbítrio do absolutismo e em defesa de um regime político em que os cidadãos, protegidos por uma Constituição, participam da administração do Estado." (VOVELLE, Michel. A Revolução Francesa explicada à minha neta. Tradução de Fernando Santos. São Paulo: Unesp, 2007, p. 17-18)

8 Jules Michelet, a propósito do funcionamento "incompreensível" do Ancién Régime afirma: "O que havia de mais tirânico na velha tirania era sua obscuridade [...]." (apud ROUANET, Sérgio Paulo. Olhar lluminista, p. 129)

9 O lluminismo é uma tendência duradoura, caracterizada por uma atitude racional e crítica, que tem como função o combate ao mito e ao poder, e que "Aplicada ao homem e às instituições humanas, [...] significa que não há mais zonas de sombras no mundo social e político. [...] Não há mais interditos, espaços extraterritoriais protegidos pelo privilégio da invisibilidade [...] Não há mais investigações proibidas [...]." (ROUANET, Sérgio Paulo. Olhar Iluminista. In: NOVAES, Adauto et al. (orgs.). O Olhar. São Paulo: Cia. das Letras, 1988, p. 125 e 129).

$10 \mathrm{Na}$ época anterior ao lluminismo, privilégios eram "[...] distinções, tanto úteis como honrosas, dadas a certo [sic] membros da sociedade e recusadas a outros." Les nobles et privilegies era frase corrente nos documentos oficiais franceses, pela qual se entendia simplesmente os nobres e outras pessoas privilegiadas que estão isentas da taille e dos impostos ou outras obrigações que the estão associadas. (BEHRENS, Catherine B. A. O Ancien Régime. Tradução de Ana Lúcia de Sena Lino. Lisboa: Verbo, 1967, p. 45). 


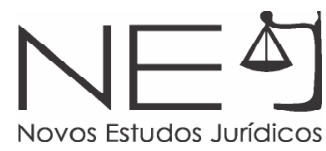

várias ordens, eram sociedades organizadas hierarquicamente (estamentos) - expressões de uma profunda crença na desigualdade, na autonomia, na diversidade, na hierarquia e na disciplina.

Os privilégios dividiam-se em honoríficos e úteis. Os primeiros conferiam prestígio, tais como o direito que um nobre tinha de usar a espada ou de ter um assento reservado no coro da igreja. Já os segundos conferiam benefícios materiais, como o direito dos nobres e dos burgueses de isenção de taille. ${ }^{11} \mathrm{Na}$ França, os principais espaços de poder e prestígio pertenciam aos membros do Primeiro e do Segundo Estado, constituídos respectivamente pela Igreja e pela nobreza. Todavia, a difusão da ideia de que só estes Estados ou ordens gozavam de privilégios é consequência de uma confusão quanto ao sentido da palavra "privilégio", bem como a propaganda corrente nos anos posteriores a 1780.

A mudança operada no significado do termo pelos iluministas envolve a ideia de que o significado do privilégio passe a ser uma espécie de vantagem, geralmente passível de ser transformada em riqueza, não obtida por serviços prestados à comunidade, mesmo que no período anterior o termo significasse a posse de direitos legais, às vezes hereditários, que em virtude do consentimento real beneficiavam várias categorias de pessoas. Uma pessoa privilegiada era aquela "que vivia em circunstâncias felizes sem que tivesse feito algo para merecer", mesmo que não se considerasse que muitos membros de ordens privilegiadas viviam de modo miserável, eis que seus direitos legais de nobre acabavam por não Ihes conferir necessariamente riqueza ou privilégio. No século XVIII, a nobreza continental era uma categoria legal sem que fosse uma classe social, entendida esta última como um grupo de pessoas com semelhantes formas de vida e rendimentos. ${ }^{12}$

11 "E porque o privilégio podia tomar tantas formas diferentes e penetrava em tantas esferas da vida social, política e económica, todos, excepto os que não tinham domicílio ou ocupação fixos, tinham privilégios num grau variável, pois todos pertenciam a um ou mais grupos com direitos especiais. Quando porém, o assunto foi discutido durante o Ancien Régime (e não havia nenhuma assunto que fosse mais posto em causa) mereceram atenção especial as chamadas 'ordens privilegiadas'." (BEHRENS, Catherine B. A. O Ancien Régime, p. 52).

12 "Na alta Idade Média, quando a principal ocupação e prazer do nobre era lutar, as diferenças de posição, riqueza e prestígio, como Marc Bloch acentuou, 'não provocavam quebra profunda na consciência da unidade de classe'. Mais tarde, a importância crescente que se deu ao dinheiro, à educação e ao requinte acentuaram a distância entre ricos e pobres." (BEHRENS, Catherine B. A. O Ancien Régime, p. 54). 
As ordens privilegiadas, típicas da Idade Média, tinham mais semelhanças com o estamento militar atual do que propriamente com classes sociais específicas e eram consideradas como corpos de indivíduos sujeitos a um código de lei especial, as quais cumpriam funções específicas por meio de uma hierarquia de posição. Muitos membros das ordens ou Estados privilegiados acabavam por ser mais pobres do que alguns integrantes do Terceiro Estado; e sendo constituída por um grupo de pessoas tão heterogêneo, era natural que esta ordem não pudesse estar sujeita a leis comuns, nem ser dotada de direitos especiais, composta por todos os que não fossem nobres ou não pertencessem ao clero: camponeses, trabalhadores urbanos, profissionais, comerciantes e outros membros da comunidade dos negociantes.

O mais famoso ataque aos privilégios foi a obra Qu'est-ce que le Tiers État, escrita pelo Abade Sieyès (1748-1831) e publicada nos alvores da Revolução Francesa. ${ }^{13}$ Tomada por muitos escritores que o sucederam como uma observação real dos fatos, tratava-se, em realidade, de "propaganda e de chamamento a luta". Nela, o autor tenta demonstrar que os integrantes das ordens privilegiadas eram as únicas pessoas a deterem privilégios na França. Eles eram comparados a "tumores vegetais que vivem ùnicamente [sic] da seiva de plantas que ... sugam até as fazerem secar." Para Behrens, Sieyès levou seus contemporâneos e as gerações seguintes a um erro, visto que:

O privilégio não podia ser, como propõe Sieyès, comparado com um tumor que se pode retirar com simples operação; devia, com mais exactidão, ser comparado com um cancro. O privilégio, no sentido de direitos legais, muitos dos quais isentavam os seus possuidores do que mais tarde se veio a considerar como obrigação comum de qualquer cidadão, era parte integral da ordem social. Desde tempos imemoriais parecera ser requisito prévio de toda actividade social, da mesma forma que a igualdade perante a lei o passou a ser no século XIX. ${ }^{14}$

13 SIEYĖS, E. J. O Que é o Terceiro Estado? Tradução de Norma Azeredo. Rio de Janeiro: Liber Juris, 1986.

14 BEHRENS, Catherine B. A. O Ancien Régime, p. 58 
Foi a tendência a uma "proliferação assustadora" de privilégios o que acabou por tornar impossível a tarefa de governar no período anterior à Revolução. ${ }^{15}$

As dificuldades para reformar as leis, considerando que elas continham muitas exceções, destruíam as bases sobre as quais os administradores trabalhavam, o que ameaçava a administração francesa, e um pouco mais tarde, as administrações das outras monarquias do continente, de um "caos total". Nestas circunstâncias, um grande número de administrativistas e escritores, dentre eles o próprio Sieyès, passou a buscar uma solução na elaboração de um direito a que todos os cidadãos estivessem submetidos.

Desse modo, a combinação de variadas causas acabou por destruir dois dos mitos estruturantes do absolutismo ocidental: a arbitrariedade de um poder de governo não limitado pela lei e, além disso, o caráter ilusório do poder real.

\subsection{UM NOVO MÉTODO PARA ANALISAR A REVOLUÇÃO}

Também a investigação de Alexis de Tocqueville (1805-1859) sobre a Revolução Francesa ${ }^{16}$ enfatiza mais o período anterior a 1789 ("Antigo Regime") do que a fase pós-revolucionária. As ideias universais que explodem de modo violento nesta ocasião incidem sobre uma sociedade em que a Igreja havia se tornado uma instituição política desvinculada da população e a nobreza não podia ser caracterizada como uma classe dirigente e mais como uma casta.

No plano político essa nobreza encontra-se desvinculada do poder real (ela foi privada de seus poderes administrativos locais, sem com isso ter adquirido um poder governamental; ela é completamente impotente para contrapor-se ao rei em nome do povo, ou para influenciar realmente o rei contra o povo). ${ }^{17}$

15 Behrens acentua as "proporções grotescas" assumidas pelos privilégios na França do século XVIII "Os monarcas, particularmente os monarcas absolutistas, usufruindo de maiores oportunidades que os seus predecessores, sempre tinham vendido os seus privilégios por dinheiro ou os tinham dado em troca de serviços que não podiam pagar. [...] Luís XVI financiou em grande medida suas guerras vendendo lugares, muitos dos quais acarretavam títulos de nobreza, e direitos subsequentes, todos conferindo imunidade num grau variável em relação a obrigações nacionais." (BEHRENS, Catherine B. A. O Ancien Régime, p. 58-9).

16 Vide TOCQUEVILLE, Alexis de. O Antigo Regime e a Revolução. Tradução de Yvonne Jean. 3.ed. Brasília: UnB; São Paulo: Hucitec, 1989. 212p.

17 FURET, François. Pensando a Revolução Francesa. Tradução de Luiz Marques e Martha Gambini. 2.ed. São Paulo: Paz e Terra, 1989, p. 147 
No plano econômico, observa-se o que Tocqueville denomina de "democratização da nobreza", visto que a redistribuição das fortunas se deu em proveito do detentor da riqueza mobiliária, o Terceiro Estado. Como consequência tem-se a fragmentação dos domínios mobiliários e o esfacelamento da nobreza em uma multidão de indivíduos de fortuna média. Neste ponto, a análise de Tocqueville se aproxima daquela de Sieyès, ao afirmar que a promoção do Terceiro Estado acaba por realizar-se de modo independente da nobreza, com "a criação de um novo povo" com sua própria aristocracia ou elite, o que irá explicar o espírito revolucionário desse Terceiro Estado. O princípio aristocrático acabou por rapidamente desaparecer, parcialmente influenciado pela fusão igualitária entre a nobreza e intelectuais e pelo poder social da intelligentsia. A grande consequência política desse momento da sociedade civil foi - ao contrário da característica das sociedades aristocráticas - a tendência ao governo centralizado. A preponderância política de Paris sobre o restante do território francês, a necessidade de consolidar uma unidade nacional frente a províncias diversas e a natureza pessoal e não parlamentar do poder serão fatores secundários que acabaram por reforçar estas causas gerais.

Para Otávio Frias Filho, a genialidade da análise de Tocqueville sobre a Revolução ${ }^{18}$ reside muito mais no método que sugere do que na tese que defende, preocupado que estava em explicar não a ruptura, mas a continuidade. Com a utilização desta metodologia consegue suprimir a legitimidade da resistência social contra o Estado central. O problema com o qual trabalha é o do verdadeiro "assenhoreamento do corpo social pela administração", visto não só como um traço de permanência que une o Antigo ao novo regime, e sim como um fator que explica a penetração da ideologia igualitária ou democrática no Antigo Regime. A inversão desconcerta: foi a centralização do Antigo Regime - e não o feudalismo, pois no período a ordem feudal era mantida só nas aparências

18 "Na mesma época em que Michelet concebeu a mais penetrante das histórias da Revolução já escritas sob o modo de identidade - uma história sem conceitos, feitas de achados do coração, marcada por uma espécie de adivinhação das almas e dos autores - Tocqueville imagina, e ele foi o único a tê-la imaginado assim, a mesma história, sob o modo inverso da interpretação sociológica. Portanto, a questão não é que o aristocrata normando não compartilhe das mesmas opiniões que o filho do impressor jacobino: Tocqueville não escreveu, por exemplo, uma história da Revolução que se encontra mais 'à direita' que a de Michelet. Ele escreveu uma outra história da Revolução, fundada em uma crítica da ideologia revolucionária e daquilo que constitui, na sua opinião, a ilusão da Revolução Francesa sobre si própria." (FURET, François. Pensando a Revolução Francesa, p. 28). 


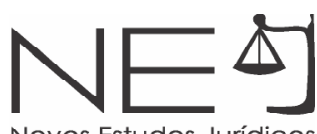

- que produziu a Revolução. Como desde o século XVI o rei havia passado a enfeixar uma soma crescente de poderes, segue-se que a centralização não fora efeito da Revolução. Gradativamente a administração passara a ser função de um corpo de profissionais/funcionários diretamente vinculado ao Conselho do Rei. Permaneciam as isenções tributárias, honrarias e títulos da nobreza, bem como os da Igreja, ao mesmo tempo em que era aniquilada a autonomia das cidades, das províncias e dos juizados locais e as antigas liberdades feudais.

O governo central açambarcara as atribuições de tributar, recrutar milícias, manter a ordem pública, realizar obras, tabelar preços, confiscar terras e assim por diante. A imagem que ele usa é a de um edifício novo e invisível que fora construído aos poucos por baixo do velho. Quando sobreveio a revolução, em 1789, tudo o que ela precisou fazer foi sacudir o edifício antigo, que se desmanchou em pó, revelando o verdadeiro aparelho governamental, cujo controle então é transferido das mãos de um monarca reformista para uma 'assembleia irresponsável e soberana', disposta a implantar o terror como política a ser executada em nome da razão, da liberdade e da igualdade. ${ }^{19}$

Em "O Antigo Regime e a Revolução" (1856), o autor afirmou categoricamente que a tradição de centralismo despótico do absolutismo havia retornado com mais força com os jacobinos e Napoleão. No caso francês, o advento da Revolução e o da democracia ocorrem em uma situação em que os "costumes" não oferecem o "leito apropriado": o despotismo estava sendo preparado há longo tempo pela nobreza e sobreviveria à própria Revolução. Esta análise possibilitou o diagnóstico de que a França (em decorrência da atomização da sociedade produzida pelo centralismo administrativo ${ }^{20}$ ) era propensa a governos autoritários, estabelecendo uma conexão entre 1789 e 1848, ficando demonstrada a "profunda continuidade que une as sociedades francesa pré e pós-revolucionária". ${ }^{21}$

19 FRIAS FILHO, Otávio. A Descoberta da democracia: o conservador visionário. Folha de São Paulo. Caderno “Mais!". 31 de julho de 2005, p. 4

20 Sobre o direito administrativo francês no período pós-revolucionário, observa Dalmo Dallari que o ambiente do início da história constitucional francesa era o de "uma verdadeira obsessão pela garantia da liberdade individual". Como corolário, tem-se o abandono da atenção às atividades administrativas, tais como obras que garantissem o abastecimento de água, já que elas não eram uma ameaça à liberdade individual. "Uma consequência dessa omissão foi que se desenvolveu um verdadeiro poder administrativo, paralelo ao governo e subordinado a ele, sem que houvesse normas jurídicas fixando regras para sua existência e funcionamento. [...] Aos poucos essa prestação de serviços foi sendo objeto de consideração mais apurada, sendo tratada como uma subárea do setor público, completamente separada do setor privado." (DALLARI, Dalmo de Abreu. A Constituição na vida dos povos. Da Idade Média ao Século XXI. São Paulo: Saraiva, 2010, p. 218).

21 CHÂTELET, François; DUHAMEL, Olivier; PISIER-KOUCHNER, Evelyne. História das idéias políticas. Tradução de Carlos Nelson Coutinho. Rio de Janeiro: Jorge Zahar, 2000, p. 86 
E Tocqueville é enfático em afirmar que, apesar de seu radicalismo, a Revolução inovou menos do que acreditavam seus atores, e "se não tivesse ocorrido, o velho edifício social teria igualmente desmoronado onde quer que estivesse, aqui mais cedo, alhures mais tarde; só que teria desmoronado pedaço por pedaço, em vez de cair no abismo de uma só vez."22

É de se notar que assim como no caso dos historiadores liberais e/ou conservadores, a dupla interpretação do problema histórico das mudanças por meio de Reformas e daquelas mediante Revolução também divide em facções opostas o movimento operário. Para os primeiros, a explosão revolucionária havia interrompido o processo natural das Reformas pacíficas que estavam em desenvolvimento e ainda não haviam produzido seus frutos. Bobbio recorda que o termo "Revolução" pode ser compreendido por meio de um par de sentidos ${ }^{23}$ "como movimento (a causa ou o meio do evento) e como mudança (o efeito ou o fim do evento)" - e conclui que é possível falar em "Revolução" como movimento que não tem por efeito uma mudança radical, e "Revolução" como mudança radical, não precedida de um movimento violento, popular, súbito, etc. ${ }^{24}$

Sobre o fundamento filosófico da primeira compreensão de Revolução, Habermas ${ }^{25}$ ressalta que a autocompreensão dos revolucionários a respeito dos eventos que estavam a protagonizar nada mais era do que a restauração de antigas ordens harmônicas governadas pelas leis da natureza:

A 'evolução do direito natural' foi o conceito filosófico que a própria revolução formou de si mesma logo que, com a dissolução das colônias norte-americanas da metrópole britânica e, principalmente, com a queda do Ancien Régime em geral, foi compreendida como revolução. [...] $\mathrm{O}$ ato com o qual se introduziu a positivação do direito natural na França e na América foi uma declaração de direitos fundamentais. [...] essa declaração tinha de expressar especialmente o discernimento e

22 TOCQUEVILLE, Alexis de. O Antigo Regime e a Revolução, p. 67

23 "A célebre interpretação que Tocqueville dá à Revolução Francesa é de uma revolução como movimento à qual não se seguiu uma revolução como mudança. Desde seu primeiro escrito juvenil, solicitado por John Stuart Mill, sobre a Revolução Francesa, depois de afirmar que 'se exageram' os efeitos produzidos pela Revolução, Tocqueville sustenta que ela 'regulou, coordenou e legalizou os efeitos de uma grande causa, em vez de ser ela mesma uma causa', e conclui: 'O que a Revolução fez teria sido feito, não duvido, sem ela; ela nada mais foi que um processo violento e rápido com o auxílio do qual a situação política se adaptou à situação social, os fatos às idéias, as leis aos costumes'. (TOCQUEVILLE, De l'etat social et politique de la France avant et depuis 1789 [1836])" (BOBBIO, Norberto. Teoria geral da política: a teoria política e a lição dos clássicos. Organizado por M. Bovero. Tradução de Daniela B. Versiani. Rio de Janeiro: Campus, 2000, p. 608)

25 HABERMAS, Jürgen. Teoria e Praxis. Tradução de R. Melo. São Paulo: Unesp, 2011, p. 144 


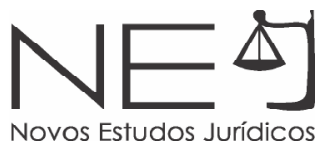

a vontade - o discernimento sobre o contexto racional das normas fundamentais e a vontade de criar validade por meio de um poder de sanção limitado por tais normas. Esse ato de declaração deveria pretender para si produzir o poder político unicamente a partir do discernimento filosófico. Essa ideia da realização política da filosofia, a saber, da criação da coerção jurídica baseada na autonomia do contrato exclusivamente a partir da coerção da razão filosófica, constitui o conceito de revolução que se segue de modo imanente dos princípios do direito natural moderno; sob o outro nome de contrato social, esse conceito foi lentamente derivado antes que a revolução burguesa - a qual se tornou consciente dele - tivesse sido concebida na positivação do direito natural e também tivesse vinculado seu próprio nome a tal conceito. ${ }^{26}$

Diferentemente da autocompreensão dos revolucionários, as análises de Tocqueville percebem o efetivo estado da sociedade. ${ }^{27}$ Elas não apelam aos direitos naturais: ao contrário, o "exemplo da Revolução Francesa mostrou-lhe que o mundo moderno situa-se inteiramente na ordem do direito positivo e que não são determinados princípios que irão deter as multidões, príncipes ou forças armadas." 28 Um exemplo é a abordagem do tema do "individualismo" em Tocqueville, diferenciando-o do "egoísmo". Egoísmo é uma categoria moral, um vício; já o individualismo é um conceito sociológico que significa a falta de uma virtude cívica ou pública. O individualismo é uma tendência ou uma característica específica das democracias, enquanto o egoísmo assola todas as épocas. Embora Tocqueville tenha admirado o vigor das reuniões municipais na Nova Inglaterra, nelas divisava não um reflexo, mas um corretivo da democracia. Por sociedade igualitária ele não pretendia designar uma sociedade de iguais e sim uma sociedade em que a hierarquia já não era o princípio aceito de estrutura social. $\mathrm{A}$ partir desta compreensão de democracia, o individualismo deixa de ser percebido como uma "patologia social, um auto-centralismo difundido, oriundo de uma sociedade igualitária dominada pelo materialismo, competição e ressentimento." Ele existiu no período anterior à Revolução, como uma característica da sociedade privilegiada. O verdadeiro individualismo da sociedade democrática moderna

26 HABERMAS, Jürgen. Teoria e Praxis, p. 148

27 Merquior considera que Tocqueville é o "sociólogo do liberalismo". (MERQUIOR, José Guilherme. O Liberalismo: antigo e moderno. Tradução de H. de A. Mesquita. Rio de Janeiro: Nova Fronteira, 1991, p. 88-89)

28 TOURAINE, Alain. O que é a democracia? Tradução de Guilherme J. de S. Teixeira. Petrópolis: Vozes, 1996, p. 119. 
havia sido precedido, na França, pela igualdade entre os indivíduos. Na medida em que os franceses se igualavam, tornavam-se também mais isolados, dividindo a nação em pequenos grupos de interesse que se invejavam entre si. Apesar de não ter adotado a crença iluminista na força civilizadora do comércio, mantevese distante de posições conservadoras que viam a Igreja e a cavalaria da Idade Média como bastiões de um mundo nobre, desfigurado pela ascensão vulgar do comercialismo. É sua posição frente ao liberalismo econômico que permite a Merquior afirmar que seu liberalismo era de natureza política e não econômica. ${ }^{29}$

Resumindo, a entrada das sociedades na Era moderna e, mais especificamente, na Era industrial, é percebida a partir de uma evolução social, isto é, de uma necessidade histórica - que pode dar-se pacífica ou violentamente - e não de uma transformação política. Esta evolução passa pelo desaparecimento das ordens ou dos Estados hierarquizados e pelo surgimento, em seu lugar, da igualdade de direitos. Esta não pode ser considerada como uma igualdade de fato e sim "uma certa igualdade de condições". Neste tocante, Tocqueville antevê o fenômeno da "alienação", decorrente da divisão repetitiva do trabalho, quando o homem deixa de pertencer a si mesmo e passa a pertencer apenas ao trabalho. ${ }^{30}$

Tendo como pressuposto que a democracia é uma "necessidade histórica", Tocqueville abraça a necessária tarefa de refletir sobre os problemas propriamente políticos dela decorrentes, entre os quais a tendência deletéria de que, no momento posterior à destruição das ordens tradicionais, a democracia acabasse por desembocar na tirania das maiorias, criando uma ordem social em contradição com a razão. A tirania levaria ao conformismo de opinião, nivelando espíritos, classes e condições. Para ele, a maioria era o coletivo de indivíduos que frequentemente têm opiniões e interesses contraditórios. É por isso que, assim como ele abomina a atribuição de todo poder ao Um, também receia a sua outorga aos muitos: os homens reunidos tornam-se mais fortes e não mais pacientes. ${ }^{31}$

29 MERQUIOR, José Guilherme. O Liberalismo: antigo e moderno, p. 89, 90-1.

30 Cf. TOURAINE, Alain. O Que é a democracia?, p. 118 e MATTEUCCI, Nicola. Organización del poder y libertad. História del constitucionalismo moderno. Presentación de Bartolomé Clavero. Traducción de Francisco Javier Ansuátegui Roig y Manuel Martinez Neira. Madrid: Trotta; Universidad Carlos III, 1998, p. 280.

31 TOCQUEVILLE, Alexis de. A Democracia na América. Tradução de Francisco Weffort. São Paulo: Abril S. A. Cultural, 1985 (Coleção: Os Pensadores/Jefferson, Federaslistas, Paine, Tocqueville), p. 240 


\section{A GÊNESE DO SURGIMENTO DA ESFERA PÚBLICA E OS FUNDAMENTOS DO CONSTITUCIONALISMO}

Para François Furet, a obra de Augustin Cochin ${ }^{32}$, dedicada à pesquisa da campanha eleitoral na Borgonha e na Bretanha no período anterior à Revolução, concorda com a convicção de Karl Marx de que "os homens que fazem a história não sabem a história que fazem," sendo o trabalho do historiador criticar as racionalizações feitas pelos atores por meio de suas representações, diferenciando vivência dos acontecimentos do pensamento crítico sobre ela. Neste sentido, para Cochin, o fenômeno central da Revolução fora o jacobinismo, percebido como um tipo de sociedade difundida na França a partir da segunda metade do século XVIII, denominada de "sociedade de pensamento" e que se manifestou nas sociedades e círculos literários, lojas maçônicas, clubes culturais e patrióticos. ${ }^{33}$ As sociedades de pensamento conformaram um tipo de socialização diversa da socialização dos "corpos", ordens ou Estados do Antigo Regime. Seu princípio basilar consistia em que - para que seus membros pudessem ali desempenhar seu papel - era necessário que se desembaraçassem de todas as particularidades concretas de sua existência social real, o que acabou por prefigurar um aspecto importante do funcionamento da própria democracia, dado que cada um de seus integrantes teoricamente era aceito apenas por suas ideias. Diferentemente de Tocqueville - que percebia na democracia uma tendência para a igualdade real das condições econômicas e sociais -, para Cochin o principal aspecto da democracia residia em ser um sistema político baseado na igualdade abstrata dos indivíduos. O jacobinismo configurou-se, então, na variante francesa da democracia, extraindo suas origens nas sociedades literárias e filosóficas. Nelas o objetivo era opinar e não agir, delegar ou representar e, com isso, buscar um consenso que tendia a alcançar o "conjunto do tecido social".34

32 Sobre o historiador francês Augustin Cochin (1876-1916), Furet comenta: "Desobrigado, pela fortuna familiar, de qualquer obrigação profissional, e vivendo, aliás, como um beneditino, ele consagrou sua curta existência a duas pesquisas fundamentais: a primeira refere-se à campanha eleitoral de 1789, inicialmente na Borgonha, depois na Bretanha. Augustin Cochin, mobilizado em 1914, foi morto no front em 1916. Seu colaborador, Charles Charpentier, publicou em 1925 o único livro concluído que ele deixou: 1. [...] Trata-se seja de pesquisas sobre as eleições de 1789, e especialmente de um artigo sobre a campanha eleitoral na Borgonha; seja de análises de natureza teórica sobre o fenômeno revolucionário, e sobre aquilo que, para Cochin constituía sua manifestação principal, o jacobinismo." (FURET, François. Pensando a Revolução Francesa, p. 176-7)

33 "[L]a nueva fase revolucionaria aceleró la participación popular. Alumbró formas de intervención pública de amplio porvenir, como el periodismo político o los 'clubes', antecedentes directos de los modernos partidos políticos" (PISARELLO, Gerardo. Un largo Termidor. Madrid: Trotta, 2011, p. 77-8).

34 FURET, François. Pensando a Revolução Francesa, p. 182, 185 e 186. 
O modo de ação ou o mecanismo de funcionamento da sociedade de pensamento pressupôs o que Louis Dumont ${ }^{35}$ considerou como sendo o fim da "sociedade holística", a desagregação do social em indivíduos e a decadência da autoridade tradicional e da solidariedade corporativa. A sociedade de pensamento determina o surgimento de uma nova relação política em que se pode perceber o delineamento da vontade geral de Rousseau. O modelo de democracia que estas sociedades prefiguram não é a representativa, e sim a democracia pura. Com a expansão jacobina da República de intelectuais, a situação repetiu-se nacionalmente: o governo do povo por ele mesmo era tecnicamente impossível, sendo substituído por sociedades permanentes de discussão. ${ }^{36}$

Atuando por meio de pequenos grupos de militantes, as sociedades de iguais passaram a constituir imaginariamente a realidade histórica. Estes grupos eram "[...] a máquina 'oculta' na sombra do 'Povo'[...] Oligarquia anônima, companhia de homens obscuros, medíocres, sucessivos, intercambiáveis, Brissot, Danton, Robespierre são mais produtos jacobinos do que líderes jacobinos." O que hoje se considera como líderes revolucionários foram mais instrumentos provisórios nas diferentes fases da Revolução, sem que eles tivessem tido liberdade para influenciar pessoalmente o seu próprio curso. E uma das leis de funcionamento desta máquina foi a dos sucessivos expurgos: "Aqueles que 'dão as cartas' são na verdade meras engrenagens, e os manipuladores são manipulados, prisioneiros da lógica do sistema." ${ }^{37}$

A Revolução é um produto de um fenômeno que surge gradativamente e se consolida na denominada opinião pública, compreendida por Jellinek em grandes linhas como "o ponto de vista da sociedade sobre assuntos de natureza política e social". ${ }^{38}$ Em razão de esta opinião envolver o monopólio do poder e da esfera pública, privando a sociedade corporativa da política e relegando o indivíduo à esfera privada da moral, Nicola Matteucci ${ }^{39}$ enfatiza o vínculo

35 Cf. DUMONT, Louis. O Individualismo. Uma perspectiva antropológica da ideologia moderna. Tradução de Álvaro Cabral. Rio de Janeiro: Rocco, 1985. passim.

36 FURET, François. Pensando a Revolução Francesa, p. 187.

37 FURET, François. Pensando a Revolução Francesa, p. 189.

38 Apud BONAVIDES, Paulo. Ciência Política. 6.ed. Rio de Janeiro: Forense, 1986, p. 564, 567

39 MATTEUCCI, Nicola. Verbete "Opinião Pública". In: BOBBIO, N.; MATTEUCCI, N.; PASQUINO, G. Dicionário de Política. Tradução de João Ferreira et al. Brasília: UnB, 1986, p. 842-843 
entre opinião pública e formação do Estado moderno. Historicamente, porém, o conceito teve uma trajetória errática. Se para Hobbes a opinião pública tem uma conotação negativa, por introduzir no Estado absolutista o germe da corrupção e da anarquia, para Locke a "lei da opinião é uma verdadeira lei filosófica, servindo para julgar a virtude ou vício das ações". Em Rousseau ${ }^{40}$, a opinião pública é a "verdadeira constituição do Estado". Kant, respondendo à pergunta "Que é o lluminismo?", assevera que consiste em fazer uso público da própria razão em todos os campos; é o uso que dela se faz como membro da comunidade e dirigindo-se a ela. Este uso público tem dois destinatários. Por um lado, se dirige ao povo, para que se torne cada vez mais capaz de ser livre quando atua; por outro, se dirige ao soberano, para mostrar-lhe que é vantajoso tratar o homem não como a uma "máquina", mas segundo a sua dignidade. ${ }^{41}$

Conforme se pode perceber, para compreender de quais eram originalmente as funções da opinião pública, deve-se examinar como se dá o nascimento do Estado moderno. Com o desmantelamento da sociedade feudal, a qual era imediatamente política (cada Estado se autorregulamentava, o senhor feudal era detentor do poder econômico e político simultaneamente, não havia um órgão que detivesse o monopólio da violência legítima, etc.), surge o Estado moderno, surgimento este que se dá sob o signo da separação da esfera política - o aparelho estatal - da esfera privada dos cidadãos (o conjunto das relações sociais entre proprietários privados). Esta esfera privada acaba desenvolvendo uma dimensão "pública" à medida que começam surgir algumas instituições - jornais, salões de conferência, assembleias de cidadãos, cafés, etc. -, que irão erigir-se em lugares de discussão e polarização das correntes de opinião presentes na sociedade burguesa. Com isso, "[...] a esfera pública política [...] intermedia, através da opinião pública, o Estado e as necessidades da sociedade." ${ }^{42}$

40 ROUSSEAU, Jean-Jacques, Do Contrato Social ou princípios do direito político. Tradução de Lourdes Machado. São Paulo: Abril Cultural, 1983.

41 MATTEUCCI, Nicola. Verbete "Opinião Pública". In: BOBBIO, N.; MATTEUCCI, N.; PASQUINO, G. Dicionário de Política, p.842.

42 HABERMAS, Jürgen. Mudança estrutural da Esfera Pública: investigações quanto a uma categoria da sociedade burguesa. Tradução de Flávio R. Kothe. 2. ed. Rio de Janeiro: Tempo Brasileiro, 2003, p. 46 e 96 
Da mesma forma, Charles Taylor ${ }^{43}$ refere que a esfera pública é uma das características centrais das sociedades modernas, podendo ser entendida como uma das dimensões da sociedade civil independente da organização política. Trata-se de um espaço comum, regulamentado pelo Estado e, simultaneamente, contrário à autoridade estabelecida, que se utiliza dos diversos meios de comunicação para colocar em discussão questões de interesse comum, ou seja, públicas. As media - e até mesmo o próprio Estado - são órgãos da esfera pública cujo objetivo é evitar a concentração do poder por meio da constante busca pela mudança da base de legitimação da dominação.

A refuncionalização - de acordo com Habermas ${ }^{44}$ - da esfera pública literária dos salões permitiu que o público tomasse para si a esfera pública controlada pelo poder estatal. O objetivo da nova função era desenvolver uma racionalidade contrária à política de segredo de Estado, praticada pelas monarquias absolutistas, e reafirmar a opinião pública como única fonte legitimadora da lei geral, abstrata e racional. Do mesmo modo que, na sua evolução em esfera pública política, a esfera pública literária formou um público de pessoas privadas "[...] em que a autonomia, baseando-se na propriedade privada, busca representar-se, enquanto tal, na esfera da família burguesa realizar-se interiormente no amor, na liberdade, na cultura - em suma: enquanto 'humanidade'". A partir das categorias da esfera pública literária, foi possível unir os interesses dos proprietários privados às liberdades individuais, sendo fácil, naquele momento, identificar a emancipação política com a própria emancipação "humana".

É por meio da opinião pública que no Estado moderno a burguesia foi capaz de impor limites à atuação da autoridade, ao tempo em que se combatia o segredo como característica da atuação estatal. A própria função da opinião pública neste período corresponde à realização, no campo social, do ideal da Ilustração. Esta, por sua vez, corporifica a pretensão iluminista que apresenta, no campo político, a intenção precípua de desvendar os segredos do soberano, assim como no campo da ciência quer descortinar os segredos da natureza. ${ }^{45}$

43 TAYLOR, Charles. Uma era secular. Tradução de Nélio Schneider e Luzia Araújo. São Leopoldo: Unisinos, 2010, p. 227

44 HABERMAS, Jürgen. Mudança estrutural da Esfera Pública, p. 72

45 ADORNO, Theodor; HORKHEIMER, Max. Dialética do Esclarecimento. Tradução de G. Almeida. Rio de Janeiro: Jorge Zahar, 1985, p. 19 e 52. 


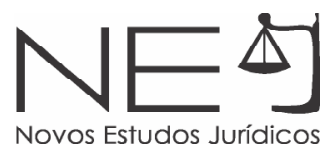

Em suma, a esfera pública foi uma mutação do imaginário social, fundamental para o desenvolvimento da sociedade moderna. Sua condição de existência foi a autoconsciência por parte dos integrantes, uma vez que, "a menos que todas as discussões dispersas sejam vistas pelos participantes como conectadas num grande intercâmbio, não pode haver nenhum sentido de resultado como 'opinião pública'". 46 Se de um lado as relações entre o império da opinião pública e a luta pela Democracia não são prima facie evidentes na llustração, é certo que algumas das mais importantes liberdades democráticas surgem neste momento. ${ }^{47}$ Fato é que a esfera pública surgiu no século XVIII como espaço metatópico num contexto em que a teoria política passou a atribuir grande importância à ideia de que a sociedade política fosse fundada no "consentimento" dos indivíduos, sendo por eles limitada. No entanto, a metatopicalidade não foi uma novidade em si, visto que Igreja e Estado também eram espaços metatópicos. A modificação introduzida pela noção de esfera pública estava relacionada à ideia moderna de ordem e, nesse sentido, duas características são destacadas: uma identidade independente do político e sua força legitimadora. ${ }^{48}$

No caso da sociedade de pensamento, uma das suas características residia em não pensar, só falar, sendo a "verdade" socializada por meio do consenso e não do pensamento, o que em outras palavras é a própria ideologia: "representações cristalizadas em algumas figuras simples da linguagem, destinadas a unificar e a mobilizar os espíritos e as vontades." Cochin chegou a afirmou que Robespierre fora investido em uma função de "vigilância", ou seja, a de velar sobre o consenso, "farejando o menor deslize." Se a ideologia fosse pensada, ela seria passível de críticas: ela apenas falou por meio de seus intérpretes. A Revolução foi uma linguagem.

46 TAYLOR, Charles. Uma era secular, p. 229

47 Como afirma Carl Schmitt, "Los filósofos de la llustración del siglo XVIII eran partidarios de un despotismo ilustrado, pero veían en una opinión pública ilustrada el control de toda la actividad estatal y una segura garantía contra cualquier abuso del poder del Estado. Libertad de manifestación del pensamiento y libertad de Prensa se convirtieran así en instituciones políticas. De ahí reciben el carácter de derechos políticos y dejan de ser secuela como en el proceso americano, de la libertad de consciencia y de religión. El ejercicio de la libertad de Prensa, de la libertad de manifestación de opiniones políticas, no solo es un ejercicio dentro de la esfera privada de la libertad, sino actividad pública, desempeño de una cierta función pública, el control público." (SCHMITT, C. Teoría de la Constitución. Traducción de F. Ayala. Madrid: Alianza, 1982, p. 242).

TAYLOR, Charles. Uma era secular, p. 230. 
Em 1793, e durante alguns meses, culminação do processo: o jacobinismo, sob a ficção do 'povo', substitui ao mesmo tempo a sociedade civil e o Estado. Através da vontade geral, o povo-rei coincide miticamente, de agora em diante, com o poder: essa crença é a matriz do totalitarismo. ${ }^{49}$

Verificou-se desse modo o funcionamento da ideologia que, para passar da sociedade de pensamento para a sociedade real, precisou recompor o social suprimindo e excluindo. Em outono de 1788, a nobreza passou a ser culpada ${ }^{50}$, transformando-se no símbolo da desigualdade: alguns nobres até podiam ser revolucionários, mas a nobreza em si foi percebida como contrária à Revolução. $\mathrm{E}$ Cochin, de acordo com François Furet ${ }^{51}$, foi o primeiro historiador a debruçar-se sobre o tema de como os franceses foram capazes de reinventar o social sob o nome de "nação", "transformando-a no novo deus de uma comunidade jurídica."

A substituição que as sociedades de pensamento promoveram da religião, do rei e das hierarquias tradicionais pela ideologia igualitária só foi possível em razão da existência de duas condições: uma filosofia política constituída por "ideias-mães" e por grandes obras individuais e a existência de um corpo tradicional que perdeu seus princípios. Uma das "ideias-mães" foi a da soberania do povo, definida sistematicamente por Rousseau. Diferentemente do direito natural, a soberania popular assim concebida era um direito inalienável que excluía a ideia de representação. Foi a Revolução que concedeu ao "Contrato Social" seu poder de irradiação intelectual, visto que se tratava de um livro abstrato demais para ser entendido pela maioria dos seus contemporâneos.

Diante do que foi dito, é surpreendente verificar que na primeira fase da Revolução e mesmo logo após o Termidor de 94, a Revolução acabou por elaborar a doutrina do regime representativo, cujo porta-voz foi Sieyès, promovendo e estendendo a delegação de poder pelo povo a todos os oficiais públicos. $^{52}$ Para o abade, a Nação só poderia ser personificada pelo Terceiro Estado, o que levava à representação.

49 FURET, François. Pensando a Revolução Francesa, p. 191.

50 O terreno ideal para a propaganda igualitária e a subsequente exclusão da nobreza surgiram por ocasião do problema do voto "por cabeça": as sociedades "manipuladas pelos ativistas" do Terceiro Estado e juristas acabam por converter-se na "nação". (FURET, François. Pensando a Revolução Francesa, p. 204)

51 FURET, François. Pensando a Revolução Francesa, p. 198-199

52 FURET, François. Pensando a Revolução Francesa, p. 209-210. 
El poder constituyente, omnipotente e ilimitado, solo podía actuar de manera excepcional, cuando la salud de la patria así lo exigiera, para luego ceder a la lógica limitada de los poderes constituidos, institucionales. Y estos poderes constituidos, a su vez, debían funcionar a partir de una lógica que reconociera la ciudadanía activa no a todos, sino a los mejores. ${ }^{53}$

A opção por priorizar o papel da burguesia e não dos setores populares foi uma decorrência da necessidade de representação do Terceiro Estado e da soberania, capaz de diferenciar entre um poder constituinte ilimitado e excepcional e poderes constituídos representativos e censitários. De qualquer sorte, é preciso lembrar que no período revolucionário não foi possível o estabelecimento de um regime representativo propriamente dito. Considerando que o destino deste sistema depende diretamente da atribuição da soberania, Jean-Yves Guiomar menciona as Constituições francesas do período para evidenciar que, se em 1791 a soberania foi atribuída à nação ${ }^{54}$, em 1793 ela passou a residir no povo ${ }^{55}$ e a de 1795 mencionou a "universalidade dos cidadãos"56. Quando no ano de 1792 o campesinato passou a ser uma força política autônoma na França - era uma imensa maioria de 25 milhões de franceses -, a questão que se colocou para os revolucionários passou a ser a possibilidade ou não de estabelecer uma República com uma população tão vasta. Se a resposta de Rousseau havia sido negativa, a posição das comunas, resultante da Constituição de 1791, foi diversa.

53 PISARELLO, Gerardo. Un largo Termidor, p. 74-5

54 "Todo el edifício institucional de la Constitución de 1791 giraba en torno de la idea de que la Nación ejercía sus poderes mediante representantes. No obstante, dejaba claro que estos debían elegirse mediante sufrágio censitario y excluyente. Para posiciones protoliberales como la de Sieyès, el sufragio no constituía en realidad un derecho, sino una función pública para la cual había que demostrar cualidades." (PISARELLO, Gerardo. Un largo Termidor, p. 75)

55 A Constituição de 1793 "[e]stableció el sufragio universal masculino y dispuso que las leyes quedaran sometidas a sanción popular [...] se amplió la Declaración de derechos de 1791, incluyendo una serie de derechos sociales [...] La Constitución de 1793 representó uno de los puntos más altos del momento democrático de la Revolución francesa. Por primera vez, la soberanía recayó en el Pueblo, antes que en la nación." (PISARELLO, Gerardo. Un largo Termidor, p. 80-1).

56 Recordando-se que ela refletiu, em todo caso, o retrocesso termidoriano: "El derecho al sufragio,...se restringia. De los derechos sociales reconocidos por la Constitución de 1793 no quedaba rastro, y menos aún el derecho a la insurrección." (PISARELLO, Gerardo. Un largo Termidor, p. 85). 
$\mathrm{Na}$ esfera das relações locais instituiu-se uma democracia incontestável. ${ }^{57} \mathrm{~A}$ pouca representatividade das assembleias acabou por somar-se um número pequeno de votantes. Em 1791, cerca de 9/10 dos cidadãos ativos se abstiveram. Instaurado o sufrágio universal masculino em dois níveis para as eleições da Convenção, repetiu-se a baixa mobilização dos eleitores. ${ }^{58} \mathrm{Em} 1792$, com a traição de Luís XVI e a vacância do poder executivo, o sistema representativo concebido pelos revolucionários sofreu um desequilíbrio. A Convenção, oprimida por uma guerra interna e externa, precisou acumular as funções legislativa e executiva, contrapondo-se ao sistema representativo. Esta acumulação foi percebida então como um "confisco" do próprio poder.

Robespierre vê o problema, e em 24 de abril de 1792, ao apresentar seu projeto de Declaração dos Direitos à Convenção diz: 'Em caso algum a vontade soberana se representa, ela é presumida. O mandatário não pode ser representante...' Mas o problema ia muito além de uma questão de terminologia. ${ }^{59}$

Fato é que a democracia vai muito além de seus aspectos meramente políticos. Por um lado, a democracia é o regime em que os incluídos na esfera do poder político são sujeitos de direito com poderes para influir sobre os mecanismos da tomada das decisões que terão que executar; por outro o ideal democrático abrange a totalidade da vida. Com a quase fatal onda de oposições à primeira coalizão - a partir da primavera de 1793 -, os acontecimentos revolucionários acabaram por fazer com que o movimento democrático necessitasse defender as conquistas políticas e sociais do período anterior, capazes de dar aos cidadãos meios econômicos e sociais suficientes para fazer com que estas conquistas fossem integradas em sua vida pessoal. ${ }^{60} \mathrm{~A}$ tese é a

57 Apesar de que "[...] a instauração do censo e a eleição a vários graus (mais de 4 milhões de cidadãos ativos, mas apenas 50.000 eleitores efetivos) atestavam a desconfiança da burguesia em relação ao povo no plano das instituições nacionais, os constituintes avançam uma concepção muito precisa da representação. Os efeitos do sistema censitário logo se fazem sentir, no que se refere à debilidade da representação camponesa. Assim, na Bretanha, entre 41 deputados à Assembléia Legislativa, quatro são agricultores [...]" (GUIOMAR, Jean-Yves. Valores e antecipações. In: VOVELLE, Michel (org.). França revolucionária (1789-1799). Tradução de Denise Bottman. São Paulo: Brasiliense, 1989, p. 432)

58 GUIOMAR, Jean-Yves. Valores e antecipações, p. 434-5.

59 GUIOMAR, Jean-Yves. Valores e antecipações, p. 433.

60 "La aportación principal de Robespierre al proceso revolucionario fue seguramente la recuperación de la noción clásica de democracia, identificada ahora con el gobierno de las clases populares, medias y plebeyas. Fue el primero...en acuñar la divisa trinitária: 'Libertad, Igualdad, Fraternidad'." (PISARELLO, Gerardo. Un largo Termidor, p. 79). 
de que "desde o princípio, a democracia é um movimento e um combate, que vai além do político em sentido estrito." Em outras palavras, a Revolução foi responsável por desenvolver os conceitos de democracia econômica, social e cultural, para além da democracia meramente política. ${ }^{61}$

Um novo mundo havia sido fundado pela opinião - produzida nos cafés, nas lojas maçônicas, nos salões e nas sociedades. Ela passou a estruturá-lo com base no indivíduo e não mais em grupos institucionalizados. Apesar de não se estender ao povo em sua totalidade, pode-se afirmar que a opinião pública acabou por configurar uma "sociabilidade democrática", exprimindo assim o modo horizontal e basilar por meio do qual suas linhas de comunicação formaram-se a partir "de uma sociedade desagregada", ponto em que todos os homens eram iguais. "A 'opinião' é precisamente essa maneira obscura de dizer que algo se recompôs sobre o silêncio que envolve a pirâmide dos interlocutores tradicionais do rei da França, e a partir de princípios novos, mas que não estão claros para ninguém." ${ }^{62}$

61 Mesmo que as modalidades de sufrágio tenham acabado por dar à vida democrática uma menor extensão, a Revolução instaura a possibilidade de amplo acesso aos empregos, bem como a eleição para todas as funções públicas. De acordo com Guiomar não pode ser minimizado o fato de que a abolição das fórmulas do Antigo Regime levou a uma alteração nas relações de civilidade no sentido da igualdade. "Nas milícias comunais, na Guarda Nacional, nos corpos de voluntários, nas sociedades populares e nas seções, instaurou-se um vivificante igualitarismo, estimulado pela liberdade de imprensa e, ancorado na vida cotidiana. [...] As grandes transformações sociais, como a abolição definitiva da feudalidade (17 de julho de 1793), são contemporâneas deste desenvolvimento democrático." É um equívoco perceber o período entre os anos de 1795-1799 como uma mera reação, eis que, em muitos aspectos, será neste momento em que a Revolução irá se enraizar e aprofundar. Se o conhecimento é um dos grandes fundamentos da democracia, datam deste período os grandes estabelecimentos de ensino, o Instituto, as escolas centrais dos departamentos, muito embora o ensino primário tenha sido negligenciado. As monarquias que surgiriam posteriormente estiveram submetidas às leis da diplomacia e dos exércitos revolucionários. (GUIOMAR, Jean-Yves. Valores e antecipações, p. 438). 
A sociabilidade produziu opinião e não ação, não tendo se comunicado com a sociabilidade anterior. A imagem substitutiva do poder que a opinião antiga havia construído estava baseada no poder "absoluto" dos reis invertido em prol do povo. Transformavam-se as opiniões em mera "opinião", excluindo a legitimidade da representação e do desacordo. Até o início de 1789, momento em que Luís XVI conclama os franceses a redigir os Cahiers de Doléances $^{63}$, estas duas sociabilidades políticas coexistiram pacificamente. $\mathrm{E}$ Furet acrescenta: "O contingente da Revolução sai das eleições de 1789, mas a linguagem da Revolução ainda não se encontra nos Cahiers. Pois os Cahiers não falam a língua da democracia, mas a dos juristas do Antigo Regime." Apesar dos Cahiers mencionarem a "nação" a fim de reivindicar a restituição ou mesmo a fixação de direitos, fundavam a representação dos cidadãos na antiga ideia de um coletivo de direitos tradicionais anteriores à própria monarquia. Toda esta "alquimia" traduzida de modo ambíguo pela palavra Constituição ainda não continha a ideia de vontade do povo e muito menos o que a democracia direta acabaria significando para os clubes revolucionários. Na mesma proporção em que o funcionamento estrutural dos Estados Gerais passava a ser o de um sistema representativo, a ideia de uma igualdade natural germanista era adaptada a uma teoria moderna dos poderes, na medida em que transformam a estrutura dos Estados Gerais em sistema representativo. ${ }^{64}$

Todavia a ideologia revolucionária nasceu nas batalhas da eleição e não nos Cahiers. Estas batalhas eram só na aparência marginais, visto que excluíram os homens, dando primazia à vontade popular. ${ }^{65}$ Muito mais que

63 Sobre o significado dos Cahiers, Michel Vovelle explica: "Uma dolência é uma queixa - não se ousa dizer uma reclamação - submetida à boa-vontade do rei. Os franceses levaram muito a sério essa tarefa; cada ordem tinha seu caderno, e os membros do Terceiro Estado, nas aldeias ou nas corporações, relatavam suas misérias de maneira frequentemente emocionante, sendo às vezes 'teleguiados' por pessoas instruídas que faziam passar reivindicações mais gerais. Nessa altura dos acontecimentos, os súditos ainda amam o rei, que é visto como uma espécie de pai, mas eles denunciam os abusos da administração e os direitos senhoriais; não se importam de pagar imposto, mas exigem o direito de controlá-lo por meio de seus representantes, e reivindicam o respeito pelas liberdades e o fim do arbítrio [...]." (VOVELLE, Michel. A Revolução Francesa explicada à minha neta, p. 26-7).

64 FURET, François. Pensando a Revolução Francesa, p. 56

65 Sobre o surgimento/descoberta de uma nova política, François Furet afirma "Robespierre só se torna Robespierre no momento em que Ihe é necessário conquistar seu lugar de deputado no Terceiro Estado de Arras: o jovem conformista inventou o discurso da igualdade. Da mesma forma, o que dá a Quést-ce que Le Tiers État? sua ressonância nacional, e ao vigário geral de Chartres um posto no Terceiro Estado de Paris, é que a famosa brochura é ao mesmo tempo um discurso da exclusão e um discurso da origem. [...] 'Será que nós só mudaremos de males, ou será que a ordem social, em toda a sua beleza, tomara o lugar da antiga desordem?' (Quést-ce que Le Tiers État?, cap. IV, parágrafo 3). Pouco importa que Sieyès elabore também uma teoria da representação, pois o representável é justamente aquilo que os cidadãos possuem em comum, ou seja, o fato de terem fundado a nação contra a nobreza. Essa tautologia vertiginosa inventa o novo mundo político." (FURET, François. Pensando a Revolução Francesa, p. 59). 


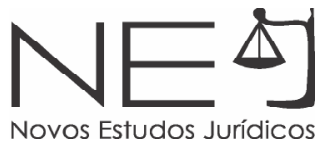

em um quadro de causas e consequências, ela foi o abismo que se abriu entre a linguagem dos Cahiers e a do Ami Du Peuple de Jean-Paul Marat, separadas temporalmente por apenas alguns meses. O significado da Revolução pode ser percebido por meio da abertura da sociedade a todas as suas possibilidades. A prática política da Revolução Francesa deixou entrever as contradições da teoria democrática inaugurando

[...] um mundo onde as representações do poder são o centro da ação, e onde o circuito semiótico é mestre absoluto da política. Trata-se de saber quem representa o povo, ou a igualdade, ou a nação: é a capacidade de ocupar essa posição simbólica, e de conservá-la, que define a vitória. ${ }^{66}$

De acordo com o historiador francês, o surgimento de uma ideologia "ingênua" que percebeu no século XX o sentido fundador da revolução-mãe tem origem na ideia de que o portador em potencial de uma segunda Revolução é o movimento socialista. Os acontecimentos acabaram como que "amputando" este sentido, eis que a Revolução Francesa deixou de ser a subversão de valores, o remanejamento dos status sociais e dos dirigentes, passando a ser a instalação do Estado e da sociedade francesa contemporânea de Mirabeau a Napoleão. A revolução burguesa havia terminado em 9 do Termidor, no momento em que finalizara também o episódio não burguês de sua história. ${ }^{67}$

Sobre este ponto, François Furet dialoga com o historiador Claude Mazauric (1932), lançando a hipótese de que para este último, apoiado em uma citação de Karl Marx, "o jacobinismo e o terror teriam sido somente uma 'maneira plebeia' de concluir a revolução burguesa e de acabar com os inimigos da burguesia." Em especial, Furet recorda a análise de Friedrich Engels em carta dirigida a Marx em que o Terror é visto como

[...] o reino dos que aterrorizam a si próprios. Em grande parte, o terror não é senão uma série de crueldades inúteis, perpetradas por pessoas que, estando elas mesmas muito assustadas, tentam se tranquilizar. Estou convencido de que devemos imputar quase inteiramente ao Reino do Terror anno 1793 aos burgueses excessivamente excitados 
que se fazem de patriotas, aos pequeno burgueses filistinos sujandose nas calças e à ralé fazendo do Terror um comércio. ${ }^{68}$

$\mathrm{Na}$ "Sagrada Família", Marx criticou a ilusão jacobina de modo não tão psicológico, ao demonstrar que no cerne dela estava a ideia do Estado virtuoso, concebido de acordo com os ideais da Antiguidade, capaz de superar os dados objetivos da sociedade civil ou, naquele momento, a sociedade burguesa moderna. Em razão da falta de raízes na sociedade, o Terror foi o Estado transformado em seu próprio fim, alienado pela ideologia, desvinculado da "burguesia liberal". Uma tal alienação do Estado, além de ter ocorrido durante a ditadura de Robespierre, também esteve presente durante o domínio napoleônico. ${ }^{69}$ Neste mesmo sentido afirma Gerardo Pisarello que, com o golpe termidoriano,

[l]a burguesía dejaría atrás las grandes palabras y extendería el 'terror blanco' a París y a las províncias, donde hubo detenciones y ejecuciones masivas de sans-culottes y de campesinos. Desde este punto de vista, Termidor no era una salida del Terror. Era su continuación con otros protagonistas, con otros vencedores y otros vencidos. ${ }^{70}$

Apesar de tudo, Furet negou-se a aceitar a ideia de que o processo revolucionário poderia ser reduzido ao conceito de revolução burguesa, mesmo considerando que esta possuísse um suporte popular. O conceito a ser aprofundado era o de crise revolucionária, mais do que o de revolução burguesa. Para a compreensão desta crise ou da dialética do fenômeno revolucionário francês, é indispensável considerar os seguintes elementos: prévia vacância do poder e do Estado, crise das classes dirigentes, mobilização autônoma e concomitante das massas populares e elaboração na sociedade de uma ideologia maniqueísta e ao mesmo tempo integradora. Neste quadro, a Revolução, mais do que o "salto" de uma sociedade para outra, foi o "conjunto das modalidades através das quais uma sociedade civil, subitamente 'aberta' pela crise do poder, libera todas as palavras das quais é portadora." E Furet complementa,

68 Correspondence Marx-Engels, 49.1870 apud FURET, François. Pensando a Revolução Francesa, p. 142

69 "Napoleão foi a última batalha do Terror revolucionário contra a sociedade burguesa, igualmente proclamada pela Revolução, e contra sua política. Napoleão também considerava o Estado como sua própria finalidade, e a sociedade burguesa unicamente como um financiador, como um subordinado, ao qual estava vedada qualquer vontade própria. Ele completa o Terror substituindo a revolução permanente pela guerra permanente." (La Sainte Famille, op. cit., p. 144-150 apud FURET, François. Pensando a Revolução Francesa, p. 142)

PISARELLO, Gerardo. Un largo Termidor, 2011, p. 86-7 


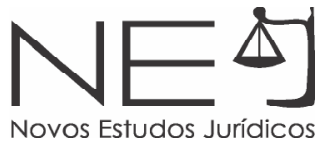

É em nome da igualdade que Robespierre faz guilhotinar Barnave e Brissot, mas é também à igualdade que Sieyès é fiel, através de tantas infidelidades aparentes, da primavera de 89 ao 18 brumário de 99. A revolução é o imaginário de uma sociedade, transformada no próprio tecido de sua história. ${ }^{71}$

Para finalizar, recorde-se que, para Habermas ${ }^{72}$, a consciência revolucionária de 1789 propiciou uma nova mentalidade sobre o tempo e sobre a prática política. Essa nova mentalidade, ao mesmo tempo que durou, trivializou-se, tendo hoje perdido o seu "poder utópico explosivo". Para pensar uma república radicalmente democrática, é necessário contar com uma "cultura popular de ressonância", abandonando certa ideia de república que acaba sendo aceita sem discussões.

\section{CONSIDERAÇÕES FINAIS}

Refletir sobre a história conceitual da Revolução Francesa passa por uma outra história, isto é, pela crítica da ideologia revolucionária ou da ilusão que a Revolução acaba por produzir sobre si. Dentre as várias causas que combinaram para destruir os mitos estruturantes do Antigo Regime e no que se relaciona ao terreno que preparou o advento de um novo mundo na política e no direito por meio da Revolução Francesa, é flagrante o modo como os iluministas acrescentaram uma nova compreensão ao termo privilégio, capaz de erigir-se em bandeira de luta contra a ordem anterior. Já no plano da teoria política, a contribuição da análise de Tocqueville se dá num plano mais vinculado ao método das transformações produzidas pela Revolução, diferenciando-as daquelas que poderiam ter sido feitas por meio de reformas. Em outras palavras, o advento das sociedades na modernidade-com o desaparecimento dos Estados hierarquizados e o surgimento da igualdade de direitos - foi feito por meio de transformações sociais que se dão ou de modo pacífico ou de modo violento e não apenas por meio de uma transformação política. 
A grandiosidade da Revolução Francesa pode ser percebida quando se recorda que ela foi capaz de colocar a natureza do sujeito de direito duplamente em relevo: por meio da ideia de nação e a de cidadania. Pela primeira, o povo se tornou consciente de sua condição de sujeito, capaz de atuar e fixar autonomamente seu destino político; e pela segunda, o homem, o cidadão, tornou-se sujeito graças à "Declaração dos Direitos do Homem e do Cidadão", estabelecendo assim balizas para a consolidação do Constitucionalismo. A renovação diária da cultura da liberdade, como quer Peter Häberle ${ }^{73}$, necessita da luta entre as diferentes compreensões de justiça em cada época e em cada sociedade e o Constitucionalismo só irá sobreviver enquanto esta cultura subsistir.

Também ficam evidentes as contribuições da história conceitual da Revolução Francesa, quando se considera o jacobinismo como um tipo de sociedade - a sociedade de pensamento - ou uma ideologia. Estas sociedades são precursoras da opinião pública, na medida em que, objetivando opinar, elas "falam" e socializam o consenso, isto é, a ideologia por meio de representações e de figuras de linguagem unificadoras, "fabricando" a unanimidade. Ali o funcionamento da democracia é prefigurado: cada integrante é aceito apenas por suas ideias num combate que vai muito além do sentido estrito do político, desenvolvendo seus aspectos econômicos, sociais e culturais. A pouca relevância e o caráter mutável dos líderes revolucionários são consequências diretas da sua instrumentalidade, decorrente do jacobinismo ou da ideologia da democracia pura.

Retornando ao tema das mudanças promovidas por reformas ou pela Revolução, sabe-se que a explosão revolucionária, seja para historiadores

73 A título conclusivo, vale lembrar a reconstrução de Häberle dos valores que surgiram com a Revolução Francesa: o caráter escrito das Constituições, bem como as estruturas formais e as partes em que se divide o conteúdo das Constituições, tais como os preâmbulos, as disposições transitórias e finais; a liberdade, igualdade e de modo mais formal, a fraternidade, ou seja, os direitos fundamentais dos indivíduos como direitos inatos (vida, liberdade, igualdade e propriedade); as declarações ou tábuas de direitos em seu conjunto, assim como os direitos singulares (por exemplo, a liberdade de expressão), antes de tudo em seus conteúdos, esferas de proteção e funções (direitos de defesa frente à intervenção do Estado) clássicos; a ideia de codificação e de positivação do direito; a doutrina do poder constituinte do povo no sentido de Sieyès ou da soberania popular e da representação; os processos de elaboração e reforma da Constituição; a ideia da separação dos poderes; o conceito de Leivontade geral, no sentido de Rousseau, junto com o procedimento legislativo; a República como forma de Estado e a ideia de Estado nacional. (HÄBERLE, Peter. Libertad, igualdad y fraternidad. 1789 como historia, actualidad y futuro del Estado Constitucional. Prólogo de Antonio López Pina. Traducción de Ignacio Gutiérrez. Madrid: Trotta, 1998, p. 77). 


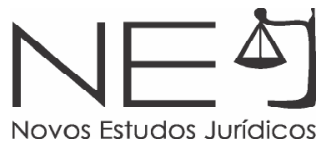

liberais ou mesmo conservadores, acabou interrompendo o processo natural das reformas pacíficas. Autores como Norberto Bobbio ${ }^{74}$ diferenciam dois tipos de compreensão da Revolução: como causa e como efeito. Pode-se ter um movimento revolucionário que não tenha como efeito uma mudança radical e uma mudança radical sem ter sido antecedida por um movimento violento. Já a percepção da Revolução como uma linguagem, como a liberação das palavras de uma sociedade civil "aberta" por uma crise de poder, complementará a análise marxista do Terror jacobino como o do "reino dos que se aterrorizam a si próprios" e o significado provisório das lideranças revolucionárias. O instrumento representado pela análise histórico-conceitual pode levar à compreensão da luta pela justiça na Revolução Francesa, muito além de um movimento incapaz de produzir uma mudança radical, e sim como uma mudança subversora do passado e estabelecedora das bases do futuro.

\section{REFERÊNCIAS}

ADORNO, Theodor; HORKHEIMER, Max. Dialética do Esclarecimento. Tradução de G. Almeida. Rio de Janeiro: Jorge Zahar, 1985. 253 p.

BEHRENS, Catherine B. A. O Ancien Régime. Tradução de Ana Lúcia de Sena Lino. Lisboa: Verbo, 1967. 214p.1

BOBBIO, Norberto. Teoria geral da política: a teoria política e a lição dos clássicos. Organizado por M. Bovero. Tradução de Daniela B. Versiani. Rio de Janeiro: Campus, 2000. 717 p. Título original: Teoria Generale Della Politica

BONAVIDES, Paulo. Ciência Política. 6.ed. Rio de Janeiro: Forense, 1986.

CHÂTELET, François; DUHAMEL, Olivier; PISIER-KOUCHNER, Evelyne. História das idéias políticas. Tradução de Carlos Nelson Coutinho. Rio de Janeiro: Jorge Zahar, 2000. 399p.

DALLARI, Dalmo de Abreu. A Constituição na vida dos povos. Da Idade Média ao Século XXI. São Paulo: Saraiva, 2010. 359p.

DWORKIN, R. Uma questão de princípio. Tradução de Luís Carlos Borges. São Paulo: Martins Fontes, 2000.

DUMONT, Louis. O Individualismo. Uma perspectiva antropológica da ideologia moderna. Tradução de Álvaro Cabral. Rio de Janeiro: Rocco, 1985.

74 Vide BOBBIO, Norberto. Teoria geral da política, p. 601. 
FERRAJOLI, L. Constitucionalismo principialista e constitucionalismo garantista. Tradução de A. K. Trindade. In: ; STRECK, Lenio Luiz; TRINDADE, André Karam (orgs.). Garantismo, hermenêutica e (neo)constitucionalismo: um debate com Luigi Ferrajoli. Porto Alegre: Livraria do Advogado, 2012. p. 13-58

FRIAS FILHO, Otávio. A Descoberta da democracia: o conservador visionário. Folha de São Paulo. Caderno “Mais!". 31 de julho de 2005, p. 4

FURET, François. Pensando a Revolução Francesa. Tradução de Luiz Marques e Martha Gambini. 2.ed. São Paulo: Paz e Terra, 1989. 231p.

GODECHOT, Jacques. A Revolução Francesa: cronologia comentada 1789-1799. Tradução de Julieta Leite. Rio de Janeiro: Nova Fronteira, 1989. 415p.

GUIOMAR, Jean-Yves. Valores e antecipações. In: VOVELLE, Michel (org.). França revolucionária (1789-1799). Tradução de Denise Bottman. São Paulo: Brasiliense, 1989.

HÄBERLE, Peter. Libertad, igualdad y fraternidad. 1789 como historia, actualidad y futuro del Estado Constitucional. Prólogo de Antonio López Pina. Traducción de Ignacio Gutiérrez Gutiérrez.Madrid: Trotta, 1998. 96p.

HABERMAS, Jürgen. Soberania popular como procedimento. Um conceito normativo de espaço público. Novos Estudos CEBRAP. Centro Brasileiro de Análise e Planejamento, São Paulo, n. 26, p. $100-113$, mar. 1990.

Mudança estrutural da Esfera Pública: investigações quanto a uma categoria da sociedade burguesa. Tradução de Flávio R. Kothe. 2.ed. Rio de Janeiro: Tempo Brasileiro, 2003. 398 p. Título original: Strukturwandel der Öffentlichkeit: Untersuchungen zu einer Kategorie der bürgerlichen Gesellschaft

Teoria e Praxis. Tradução de R. Melo. São Paulo: Unesp, 2011.

HOBBES, T. Leviatã. Tradução de J.P. Monteiro e M.B. da Silva. São Paulo: Abril Cultural, 1982.

KANT, I. Qué es Ilustración. Disponível em: http://www.inicia.es/de/diego_reina/moderna / ikant/que_es_ilustracion.htm. Acesso em: 01/08/19

LEFEBVRE, Georges. A Revolução Francesa. Tradução de Ely Bloem de Melo Pati. São Paulo: IBRASA, 1966. 574p.

La Revolución Francesa y el Imperio (1787-1815). Traducción de M. Teresa Silva de Salazar. 1.ed. 2.reimp. México: Fondo de Cultura Económica, 1970. 294p.

LOCKE, J. Segundo Tratado sobre o Governo Civil. Tradução de M. Lopes e M. da Costa. Petrópolis: Vozes, 1994. 
LÓPEZ PINA, Antonio. Prólogo. In: HÄBERLE, Peter. Libertad, igualdad y fraternidad. 1789 como historia, actualidad y futuro del Estado Constitucional. Traducción de Ignacio Gutiérrez Gutiérrez. Madrid: Trotta, 1998. p. 10)

MANFRED, A. A Grande Revolução Francesa. Tradução de M. A. de Camargo e A. da Costa Simões. 2. ed. São Paulo: Ícone, 1986. 251p.

MATTEUCCI, Nicola. Organización del poder y libertad. História del constitucionalismo moderno. Presentación de Bartolomé Clavero. Traducción de Francisco Javier Ansuátegui Roig y Manuel Martinez Neira. Madrid: Trotta; Universidad Carlos III, 1998. 318p.

. Verbete "Opinião Pública". In: BOBBIO, N.; MATTEUCCI, N.; PASQUINO, G. Dicionário de Política. Tradução de João Ferreira et al. Brasília: UnB, 1986, p. 842-843

MERQUIOR, José Guilherme. O Liberalismo: antigo e moderno. Tradução de H. de A. Mesquita. Rio de Janeiro: Nova Fronteira, 1991. 260p.

PÉRONNET, Michel. A Revolução Francesa em $\mathbf{5 0}$ palavras-chaves. Prefácio de Jacques Godechot. Tradução de Rita Braga. São Paulo: Brasiliense, 1983. 292p.

PISARELLO, Gerardo. Un largo Termidor. Madrid: Trotta, 2011. 221 p.

ROUANET, Sérgio Paulo. Olhar Iluminista. In: NOVAES, Adauto et al. (orgs.). O Olhar. São Paulo: Cia. das Letras, 1988.

ROUSSEAU, Jean-Jacques, Do Contrato Social ou princípios do direito político. Tradução de Lourdes Machado. São Paulo: Abril Cultural, 1983.

SCHMITT, Carl. Teoría de la Constitución. Traducción de F. Ayala. Madrid: Alianza, 1982.

SIEYÈS, E. J. O Que é o Terceiro Estado? Tradução de Norma Azeredo. Rio de Janeiro: Liber Juris, 1986.

TAYLOR, Charles. Uma era secular. Tradução de Nélio Schneider e Luzia Araújo. São Leopoldo: Unisinos, 2010. 930 p.

TOCQUEVILLE, Alexis de. A Democracia na América. Tradução de Francisco Weffort. São Paulo: Abril S.A. Cultural, 1985 (Coleção: Os Pensadores/Jefferson, Federaslistas, Paine, Tocqueville). p. 179-317. Título original: De la démocracie en Amérique

O Antigo Regime e a Revolução. Tradução de Yvonne Jean. 3.ed. Brasília: UnB; São Paulo: Hucitec, 1989. 212p.

TOURAINE, Alain. O Que é a democracia? Tradução de Guilherme J. de S. Teixeira. Petrópolis: Vozes, 1996. 286p. 
VOVELLE, Michel. A Revolução Francesa contra a Igreja. Da Razão ao Ser Supremo. Tradução de Lucy Magalhães. Rio de Janeiro: Jorge Zahar, 1989. 222p.

(org.). França Revolucionária (1789-1799). Tradução de Denise Bottman. São Paulo: Brasiliense, 1989. 563p.

A Revolução Francesa explicada à minha neta. Tradução de Fernando Santos. São Paulo: Unesp, 2007. 101p. 